\section{CRUDE OIL BIOREMEDIATION BY INDIGENOUS BACTERIA ISOLATED FROM OILY SLUDGE}

Nur Hafizah Azizana, Kasing Ak Apunb, Lesley Maurice Bilungb, Micky Vincentb, Hairul Azman Roslanb, Awang Ahmad Sallehin Awang Ahmad Husainib*

aDepartment of Biotechnology, Kulliyyah of Science, International Islamic University Malaysia, Kuantan Campus, Jalan Istana, Bandar Indera Mahkota, 25200, Kuantan, Malaysia

bDepartment of Molecular Biology, Faculty of Resource Science and Technology, University Malaysia Sarawak, 94300, Kota Samarahan, Sarawak, Malaysia
Article history

Received

7 July 2015

Received in revised form

9 October 2015

Accepted

31 January 2016

*Corresponding author haahmad@unimas.my

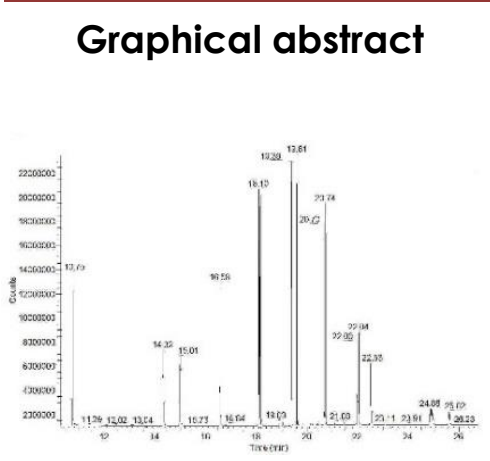

\begin{abstract}
Enrichment culture technique leads to the discovery of six presumptive TPH-degrading bacteria. Identification and characterization tests using morphological, biochemical and molecular techniques have successfully isolated Pseudomonas aeruginosa (UMASIPF), Serratia marcescens (UMAS2SF) and Klebsiella spp. (UMAS3KF). All strains were able to use crude oil as sole carbon and energy source for their growth since they were able to survive in Minimal Salt medium supplemented with $1 \%(\mathrm{v} / \mathrm{v})$ crude oil. Growth study showed that they produced the highest cell counts on the third or fourth day by $10^{8}-10^{11} \mathrm{CFU} / \mathrm{ml}$. Six artificial consortium inoculums have been produced from the growth study. Gas chromatography analysis showed that all isolates had the ability to degrade aliphatic hydrocarbon with $100 \%$ degradation of $\mathrm{nC}_{19}-\mathrm{C}_{24}$. Among the isolates, UMAS2SF was the best and fastest $n$-alkane degrader with degradation percentage between $55-90 \%$ of $n$ $\mathrm{C}_{14}-\mathrm{C}_{18}$ in 14 days. This was followed by UMASIPF and UMAS3KF with $11-82 \%$ and $1.3 \%$ degradation, respectively. Enhancement study showed that plot with inoculum and NPK addition successfully enhanced $n$-alkane degradation. Plot A2:B3+NPK degraded $n$-alkane the fastest followed by plot treated by $C+N P K, A 1: B 2, B+N P K$ and A2:B3. Result showed that UMASIPF was the best PAHs degrader as most of the high molecular weight PAHs was degraded. In the enhancement study, the plot amended with A2:B3 showed the highest PAHs degradation, followed by plots $\mathrm{A} 1: \mathrm{B} 2, \mathrm{~A} 3: \mathrm{B1}: \mathrm{C} 2$ and $\mathrm{A} 1: \mathrm{C} 3$ that was assigned as the third, fourth and fifth best in mineralizing PAHs, respectively.
\end{abstract}

Keywords: Aliphatic hydrocarbon, consortium, PAHs, n-alkane degrader

(C) 2015 Penerbit UTM Press. All rights reserved

\subsection{INTRODUCTION}

The need in petroleum and by-products to cover for a tremendous energy demand and as a primary raw material for industrialized society has brought an increasingly higher stress on the natural environment [1]. The release of hydrocarbons into environment through industrial operations, accidental spillages and leaks or dumping of wastes are main causes of terrestrial and marine ecosystems pollution [2].
Petroleum refining activities also inescapably generates substantial volumes of oil sludge. This attracts people attention nowadays with concerns of their toxic, mutagenic and carcinogenic properties that may cause progeny's death or mutation [3]. This hazardous compound enters human body usually through the food chain, where the hazardous compound adsorbs to organic-rich soils and sediments, accumulates in fish and other aquatic organisms and transferred to human through seafood consumption [4][5]. 